\title{
Influence of different types of sessile epibionts on the community structure of mobile invertebrates in an eelgrass bed
}

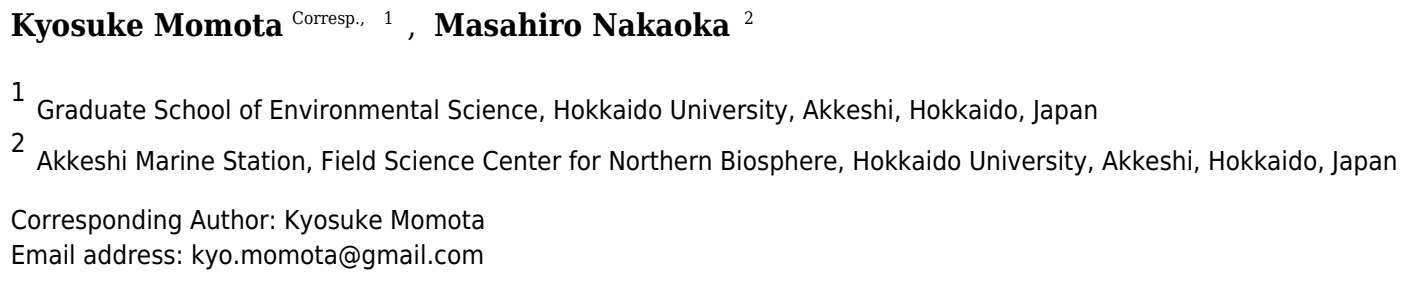

Eelgrass (Zostera marina) beds are known to have high ecological and economical values within coastal ecosystems of the temperate northern hemisphere although their biodiversity and functions varied greatly from sites to sites. The variation in the biomass, abundance and diversity of mobile invertebrates in eelgrass beds has been examined in relation to various abiotic and biotic factors, such as water temperature, salinity, eelgrass biomass and epiphytic microalgae presence. However, the importance of sessile epibionts, such as macroalgae and calcific spirorbid polychaetes attached to eelgrass blades, has not been the focus of previous studies. In the present study, we examined the effects of three different sessile epibionts, namely, branched red algae, filamentous green algae, and calcific spirorbid polychaetes, on the biomass and diversity of mobile invertebrates in the eelgrass beds of Akkeshi in northeastern Japan. The relationships between seven abiotic and biotic variables including three types of epibionts, and biomass of 11 dominant mobile invertebrate species as well as three community-level variables (the total biomass of mobile invertebrates, species richness and the Shannon-Weiner species diversity index) were analyzed using a linear mixed model. Our results show that branched red algae are correlated with Pontogeneia rostrata, Lacuna spp., Nereis sp., Syllis sp. and the total biomass of mobile invertebrates, filamentous green algae with Pontogeneia rostrata, Ansola angustata and the species diversity of mobile invertebrates, and spirorbid polychaetes with Ansola angustata, Lacuna spp., Siphonacmea oblongata, Syllis sp., the species richness and diversity of mobile invertebrates. The effect size of the epibionts was similar or even higher than that of abiotic and eelgrass factors on the total biomass of mobile invertebrates, species richness, species diversity and most of dominant invertebrate populations across the taxonomic groups. Consequently, epibiotic macroalgae and spirorbid polychaetes can be good predictors of the variation in the total biomass, species richness and species diversity of mobile invertebrates and the biomass of major 
dominant species, especially for species that have a relatively high dependency on eelgrass blades. These results suggest that the different functional groups of sessile epibionts have significant roles in determining the biomass and diversity of mobile invertebrates in eelgrass beds. 


\section{TITLE}

2 Influence of different types of sessile epibionts on the community structure of mobile

3 invertebrates in an eelgrass bed

5 AUTHORS

6 Kyosuke Momota ${ }^{1}$ (corresponding author)

7 Masahiro Nakaoka ${ }^{2}$

8

9 AFFILIATIONS

101 Graduate School of Environmental Science, Hokkaido University, Aikappu, Akkeshi, 11 Hokkaido, 088-1113, Japan.

12 E-mail: kyo.momota@gmail.com

13 TEL: +81-153-52-2056

14 FAX: +81-153-52-2042

$15{ }^{2}$ Akkeshi Marine Station, Field Science Center for the Northern Biosphere, Hokkaido University, 16 Aikappu, Akkeshi, Hokkaido, 088-1113, Japan.

17 E-mail: nakaoka@,fsc.hokudai.ac.jp

18 TEL: +81-153-52-2056

19 FAX: +81-153-52-2042 


\section{ABSTRACT}

Eelgrass (Zostera marina) beds are known to have high ecological and economical values within coastal ecosystems of the temperate northern hemisphere although their biodiversity and functions varied greatly from sites to sites. The variation in the biomass, abundance and diversity of mobile invertebrates in eelgrass beds has been examined in relation to various abiotic and biotic factors, such as water temperature, salinity, eelgrass biomass and epiphytic microalgae presence. However, the importance of sessile epibionts, such as macroalgae and calcific spirorbid polychaetes attached to eelgrass blades, has not been the focus of previous studies. In the present study, we examined the effects of three different sessile epibionts, namely, branched red algae, filamentous green algae, and calcific spirorbid polychaetes, on the biomass and diversity of mobile invertebrates in the eelgrass beds of Akkeshi in northeastern Japan. The relationships between seven abiotic and biotic variables including three types of epibionts, and biomass of 11 dominant mobile invertebrate species as well as three community-level variables

39 (the total biomass of mobile invertebrates, species richness and the Shannon-Weiner species diversity index) were analyzed using a linear mixed model. Our results show that branched red algae are correlated with Pontogeneia rostrata, Lacuna spp., Nereis sp., Syllis sp. and the total biomass of mobile invertebrates, filamentous green algae with Pontogeneia rostrata, Ansola angustata and the species diversity of mobile invertebrates, and spirorbid polychaetes with Ansola angustata, Lacuna spp., Siphonacmea oblongata, Syllis sp., the species richness and diversity of mobile invertebrates. The effect size of the epibionts was similar or even higher than that of abiotic and eelgrass factors on the total biomass of mobile invertebrates, species richness, 
47 species diversity and most of dominant invertebrate populations across the taxonomic groups.

48 Consequently, epibiotic macroalgae and spirorbid polychaetes can be good predictors of the

49 variation in the total biomass, species richness and species diversity of mobile invertebrates and

50 the biomass of major dominant species, especially for species that have a relatively high

51 dependency on eelgrass blades. These results suggest that the different functional groups of

52 sessile epibionts have significant roles in determining the biomass and diversity of mobile

53 invertebrates in eelgrass beds.

\section{INTRODUCTION}

The abundance, biomass and species diversity of marine benthic invertebrate communities vary greatly with multiple abiotic/biotic factors. The effects of temperature and salinity as environmental filters have been known to be critical factors that regulate population/community patterns and processes in coastal habitats, especially in estuaries where strong environmental gradients are generated by tidal fluctuation and freshwater inflow (e.g. Ysebaert et al., 2003; Yamada et al., 2007b; Douglass et al., 2010; Blake \& Duffy, 2010). Water temperature can either increase or decrease the abundance and diversity of component species (e.g. Somero, 2002; Harley et al., 2006; Hoegh-Guldberg \& Bruno, 2010; Meager, Schlacher \& Green, 2011), whereas a decrease in salinity generally leads to a lower species diversity and higher dominance by tolerant species (e.g. Ysebaert et al., 2003; Yamada et al., 2007b). Marine plants act as both a food resource because plant resource utilizers dominate in marine benthic invertebrate communities (e.g. Valentine \& Heck, 1999; Harley, 2006; Poore et al., 2012) and as habitat- 
70 former (e.g. Attrill, Strong \& Rowden, 2000; Lee, Fong \& Wu, 2001; Thomsen, 2010; Gartner et 71 al., 2013). distributed along the coast of the northern hemisphere (Hughes et al., 2009). The complex physical structures created by eelgrass provide a habitat for many organisms (Jernakoff, Brearley \& Nielsen, 1996; Heck, Hays \& Orth, 2003), which leads to an enhanced biodiversity and secondary production (Hemminga \& Duarte, 2000; Duffy, 2006; Valentine \& Duffy, 2006). A benthic invertebrate community in the above-ground parts of seagrass beds mainly consists of small crustaceans, gastropod mollusks and polychaetes, most of which are herbivores and detritivores (Valentine \& Heck, 1999; Heck et al., 2000). These invertebrates play an important role in mediating the energy flow in the eelgrass bed ecosystem (Duffy \& Hay, 2000; Duffy, Richardson \& France, 2005). To explore plant-animal interactions in eelgrass bed communities, traits, such as biomass, shoot density, leaf length, habitat patch structure, and epiphytic microalgal biomass of (e.g. diatoms) that serve as food resources (Attrill, Strong \& Rowden, 2000; Gartner et al., 2013; Whalen, Duffy \& Grace, 2013). However, large epibiotic organisms, such as macroalgae and sessile animals (e.g. spirorbid polychaetes, tunicates, bryozoans, hydrozoans), attached to eelgrass blades can also affect the mobile invertebrate community through resource provisioning and/or habitat modification. Despite some studies noting that the role of macroalgae on seagrass blades as a food resource or as a habitat provision can be one of the determinants of the abundance of mobile invertebrates (Valentine \& Duffy, 2006; Gartner et al., 2013; Whalen, Duffy \& Grace, 2013), most studies have focused only on the importance of seagrass and/or microalgae (e.g. Jernakoff, Brearley \& Nielsen, 1996; Heck \& Valentine, 2006). 
93 Whilst relevant studies are few, the sessile organisms such as invasive tunicates and juvenile bay

94 scallops attaching on eelgrass blade can either affect mobile invertebrates by providing refuge

95 from predation (Long \& Grosholz, 2015) and by becoming a food resource (Lefcheck et al., 96 2014). Interpreting variations in the mobile invertebrate community in relation to various

97 functional groups of epibiotic organisms that differ in size, morphology, habitat requirement and 98 life history traits is thus necessary to deepen our understanding of the organization of animal 99 assemblages in eelgrass beds and of the influences these organisms have on each other and 100 eelgrass.

An extensive eelgrass meadow, consisting mostly of Zostera marina and partly of $Z$. 102 japonica and Ruppia maritima, is located in the Akkeshi-ko estuary and the Akkeshi Bay in 103 eastern Hokkaido, Japan (Hasegawa, Hori \& Mukai, 2007). From early summer to late fall, a 104 large variety of algae and sessile animals (epibiotic species), which attach to eelgrass blades, are 105 observed, including microalgae, branched red algae, Neosiphonia sp., Chondria dasyphylla, 106 filamentous green algae, Cladophora sp., calcareous algae, Circeis spirillum, and spirorbid polychaetes, such as Neodexiospira brasiliensis, bryozoans, hydrozoans, and tunicates. Among them, microalgae, the branched red algae and the spirorbid polychaetes are dominant in eelgrass beds for a long term, between early summer and late fall, with the peak of abundance between 110 August and September (Hamamoto \& Mukai, 1999; Kasim \& Mukai, 2006; Hasegawa, Hori \& 111 Mukai, 2007; Momota, unpublished data). Previous studies on benthic invertebrate assemblages 112 in the Akkeshi-ko estuary and Akkeshi Bay have focused on their variability in relation to the 113 salinity gradient (Yamada et al., 2007a; Yamada et al., 2007b). In addition to salinity, the spatial 114 heterogeneity of other abiotic/biotic factors (e.g. water temperature, microalgal biomass and 115 eelgrass biomass) is also high in estuarine systems, such as the Akkeshi-ko estuary (Iizumi et al., 
116 1996; Kashim \& Mukai, 2006; Hasegawa, Hori \& Mukai, 2007). Nevertheless, no previous study

117 has investigated the mobile invertebrate community structure using an approach that

118 simultaneously accounts for the details of sessile epibionts and environmental control by abiotic

119 factors in the seagrass beds in Akkeshi.

120 In the present study, we investigated how multiple abiotic and biotic factors are related to

121 the variation in the community structure (total mobile invertebrate biomass, species richness and 122 species diversity) of the mobile invertebrates and the population biomass of the dominant species 123 in the eelgrass beds in Akkeshi. Our specific focus was to test the relationship between various 124 sessile epibionts on eelgrass blades and the mobile invertebrates that live on eelgrass blades. 125 Including these factors in the multivariate model, this analysis expands the classical models that 126 consider only abiotic factors, eelgrass and microalgae as the explanatory variables.

\section{MATERIALS AND METHODS}

130

131

132

133

134

135

136

137 138

\section{Study area}

The Akkeshi-ko estuary (locally called Akkeshi Lake) and Akkeshi Bay are located in Northeastern Hokkaido, Japan (Fig. 1) and are connected to each other through a narrow channel (width: approximately $500 \mathrm{~m}$, depth: approximately $10 \mathrm{~m}$ ). The Akkeshi-ko is a brackish estuary, shallow water (depth range in most of the lake: $0.8-1.7 \mathrm{~m}$ with the maximum difference in tide levels of up to approximately $\pm 0.6 \mathrm{~m}$ ), with an area of approximately $32 \mathrm{~km}^{2}$. Most bottom areas of the Akkeshi-ko estuary are muddy and covered with eelgrass (Z. marina) except for the 
139 aquaculture farms of the clam Venerupis philippinarum in the intertidal zone near the channel 140 (Kashim \& Mukai, 2006; Hasegawa, Hori \& Mukai, 2007; Yamada et al., 2007a, Yamada et al., 141 2007b). Here, freshwater input from the Bekanbeushi River, which accounts for $98.8 \%$ of all of 142 the flow volume (Iizumi et al., 1996), and tidal seawater input from the Akkeshi Bay cause steep

143 144 145 146 147 148 physical and chemical environmental gradients (Iizumi et al., 1996; Yamada et al., 2007a).

Akkeshi Bay has an area of approximately $110 \mathrm{~km}^{2}$ and opens to the Pacific Ocean at the south end. Two seagrass species Zostera marina and Z. asiatica are present from the intertidal zone to the subtidal zone ( $5 \mathrm{~m}$ below mean low water); the former occurs at depths shallower than $2 \mathrm{~m}$ and the latter dominates in deeper water (Watanabe, Nakaoka \& Mukai, 2005). The influence of the freshwater discharge on species composition of seagrass community is observed near the channel connecting the bay to the Akkeshi-ko estuary (Yamada et al., 2007a).

In this study, we established stations in the Akkeshi-ko estuary, (BK: river mouth of the Bekanbeushi River, HN: Horonitai, TB: Toubai, SL: the southern lakeside, CL: the central lake and CK: Chikarakotan) and one station in Akkeshi Bay (SR: Shinryu) (Fig. 1). BK (mean sea level, MSL hereafter: $0.9 \mathrm{~m}$ ) is located at the mouth of the Bekanbeushi River and is strongly affected by freshwater inflow. The vegetation is dense with small-sized Z. marina (average shoot length of $1.0 \mathrm{~m}$ in August). HN (MSL: $1.1 \mathrm{~m}$ ) is in a location with a high water temperature and medium salinity relative to the other stations. In addition to Z. marina, Rupia maritima, a seagrass species that is more tolerant to low-saline water, occurs at $\mathrm{HN}$. The eelgrass beds at $\mathrm{HN}$ are mostly continuous but have some gaps, and the average shoot length in August is $1.3 \mathrm{~m}$. TB (MSL: $1.1 \mathrm{~m}$ ) and SL (MSL: $1.0 \mathrm{~m}$ ) have a relatively low salinity compared to that of the other stations and are the furthest stations from the Akkeshi Bay. Although these two stations are in a similar environment, the water is often more turbid and the eelgrass bed is patchier at TB than 
162 SL. SL has a higher seagrass biomass and shoot density than TB. The average shoot length of 163 eelgrass is approximately $1.3 \mathrm{~m}$ in August at both of these stations. CL (MSL: $1.4 \mathrm{~m}$ ) and CK 164 (MSL: $1.5 \mathrm{~m}$ ) are deeper stations with a higher salinity and are dominated by longer eelgrass 165 (shoot length: 1.5-3.5 $\mathrm{m}$ at the peak season). The eelgrass at SR (MSL: $1.5 \mathrm{~m}$ ) in the Akkeshi 166 Bay, has a similar shoot size to that in CL and CK. Here, the dominant seagrass species changes 167 from Z. marina bed to Z. asiatica at a depth of approximately $2 \mathrm{~m}$, as mentioned above. not very greatly among seasons. During the summer (from July to August), eelgrass biomass, microalgal biomass and mobile invertebrates reach their peak (Hasegawa, Hori \& Mukai, 2007; Yamada et al., 2007b). Seasonal changes in the mobile invertebrate species richness are not clearly understood (Yamada et al., 2007b).

\section{Field sampling}

We conducted a field survey in August 2012. Sample collection was performed when the tidal current was slow. We collected mobile invertebrates on eelgrass blades when the water level was deeper than the average sheath length of the eelgrass at each station (BK: $20 \mathrm{~cm}$; HN, TB, SL: 30 $\mathrm{cm}$; CL, CK, SR: $40 \mathrm{~cm})$. Because the eelgrass at our study stations is tall $(>1 \mathrm{~m})$ compared to the average water depth of each station, the canopy usually reaches the water surface (except for at extremely high tides). All sampling was performed under these conditions. We targeted 182 mobile invertebrates and excluded some species with remarkably higher mobility and less dependency on eelgrass habitat, such as mysids and decapods (Yamada et al., 2007b), which were not quantitatively collected by our method (see below). 

(AAQ-175 RINKO, JFE Advantech Co. Ltd., Japan). To obtain the representative values, the sensor was carefully placed approximately $50 \mathrm{~cm}$ from the bottom to accurately reflect the environment inside of the seagrass meadow.

We collected three replicate samples (a total of 21 samples from all stations) of mobile invertebrates, spirorbid polychaetes and epiphytic macroalgae together with the entire aboveground parts of the eelgrass using a mesh bag (bore diameter: $20 \mathrm{~cm}$, mesh size: $0.1 \mathrm{~mm}$ ) based on the mouth area of the mesh bag $\left(314 \mathrm{~cm}^{2}\right)$. Upon collection, we counted the number of eelgrass shoots to determine shoot density. For microalgae, five replicate samples were collected per station together with one eelgrass shoot using a plastic zip bag, because microalgae easily fell off from eelgrass blades when collected with the mesh bag.

\section{Laboratory procedures}

Immediately after being transported to the laboratory, the microalgae were scraped from the eelgrass blades using a glass slide; separated from other organisms such as macroalgae and spirorbid polychaetes; and then filtered using glass fiber filters (Whatman GF/F filter $\varphi 47 \mathrm{~mm}$, samples, we carefully removed them from the filters with forceps. Other epibiotic organisms collected using mesh bags were separated from the eelgrass by scraping them off with a glass slide; these organisms were classified as red algae, green algae, spirorbid polychaetes and mobile invertebrates. To obtain dry mass, eelgrass shoots, red algae, green algae, spirorbid polychaetes and filtered microalgae were dried at $60^{\circ} \mathrm{C}$ for 4 days in small aluminum foil bags, and then 
208

209

210

211

212

213

214

215

216

217

218

219

220

221

222

223

224

225

226

227

228

229

230

weighed. We counted and identified the mobile invertebrates after extraction with a sieve (500 $\mu \mathrm{m}$ ) and fixation with $70 \%$ ethanol. Identification of mobile invertebrates was made to the lowest taxonomical unit possible (mostly to species) using detailed guides from the literature (Gammarid amphipod: Nishimura, 1995; Carlton, 2007; Ogawa, 2011; Caprella amphipod, Isopod, Copepod, Cumacea: Nishimura, 1995; Carlton, 2007; Gastropod: Okutani, 2000; Polychaeta: Nishimura, 1992; Imajima, 1996; Imajima, 2001; Turbellaria: Nishimura, 1992; Carlton, 2007; Hirunoidea: Nishimura, 1992) and the World Register of Marine Species online database (WoRMS: http://www.marinespecies.org).

\section{Statistical analysis}

We used, as predictors, two abiotic factors (water temperature and salinity) and six biotic factors (eelgrass biomass [g dry weight per unit area: $\mathrm{g} \mathrm{DW} \mathrm{m}^{-2}$ ], eelgrass shoot density [shoots $\mathrm{m}^{-2}$, microalgal biomass [ $\mathrm{g} \mathrm{DW} \mathrm{m}^{-2}$, red algal biomass [g DW m${ }^{-2}$, green algal biomass [g DW m${ }^{-2}$ ] and spirorbid polychaete biomass of $\left[\mathrm{g} \mathrm{DW} \mathrm{m}^{-2}\right]$ ). For eelgrass biomass, we used the dry weight data collected using mesh bags. Because microalgal biomass was collected by a different sampling procedure from other biotic variables, we used the mean value of five replicates. In this study, one of our interests was the effects of morphological traits of macroalgae and spirorbid polychaetes. Thus, we separated red and green algae by a morphological trait (red algae: branched, green algae: filamentous). All invertebrate biomass (mg ash-free dry weight per unit area, $\mathrm{mg} \mathrm{AFDW} \mathrm{m}^{-2}$ ) was estimated from the abundance and the size fraction using the empirical equations in Edgar (1990).

To test which of the eight biotic/abiotic factors was a likely predictor of the variation in 
231 the mobile invertebrate community, we fitted linear mixed models (LMMs) with a Gaussian

232 distribution (Bolker et al, 2009). The station was used as a random variable. As response

233 variables, we used the biomass of 11 dominant species for the population-level analyses, and

234 total invertebrate biomass, species richness and species diversity (Shannon-Wiener diversity

235 index; calculated based on biomass data) for community-level analyses. The 11 most dominant

236 species were selected by a threshold whereby the biomass proportion accounted for more than

$2371 \%$ of the total invertebrate biomass (see Table S1). Ostreobdella kakibir (Hirudinoidea) was

238 omitted from the analysis because it occurred only at one station (SR), even though they satisfied

239 the requirement. R software (version 3.1.3) was used for all of the analyses (R Development

240 Core Team, 2015).

241 Prior to the LMM fit, all of the variables excluding species diversity were square root 242 transformed to improve homoscedasticity and meet the assumptions of normality of the LMMs 243 after checking for normality with the Shapiro-Wilk test. To test for collinearity between the eight 244 environmental variables, we calculated Pearson's correlation coefficients for all pairs. If the 245 absolute value of the coefficient ( $r$ ) was greater than 0.7 , the level where collinearity does not 246 affect model predictions (Dormann et al., 2013), we removed the relevant predictor as necessary.

247 Because it followed that water temperature and microalgal biomass were highly correlated 248 (Pearson's $\mathrm{r}=-0.82, P<0.01$ ), we removed microalgal biomass from the models. After this 249 removal, we tested potential multicollinearity among the remaining predictors using the variance 250 inflation factor (VIF) analysis with a cutoff of 10 (e.g. Dormann et al., 2013). VIF values were 251 calculated using the vif.mer function developed by Frank 252 (https://raw.githubusercontent.com/aufrank/R-hacks/master/mer-utils.R). However, all seven 253 predictors were below the VIF value of 10 and remained. We therefore defined a reduced model 
254 with the seven predictors as the full model.

255 We fitted the LMMs using the lmer function in the lme4 package (Bates et al., 2014). To 256 obtain $P$-values of the LMMs, we used the lmerTest package (Kuznetsova et al., 2014). We 257 selected the optimal model comparing the candidate models on all combinations of the predictors 258 by the Akaike information criterion as corrected for the small sample size $\left(\mathrm{AIC}_{\mathrm{c}}\right.$ : Burnham \& 259 Anderson, 2002). We obtained $\mathrm{AIC}_{\mathrm{c}}$ based on the maximum likelihood (ML) for comparisons 260 among the LMMs because the restricted maximum likelihood (REML) is inappropriate in the 261 case when the fixed structure is different between the candidate models (Zuur et al., 2009), but 262 the parameters were estimated by REML. We used the $A I C_{c} t a b$ function in the $b b m l e$ library 263 (Bolker \& R Core Team, 2013) to compare the $\mathrm{AIC}_{\mathrm{c}}$. After setting the optimal models, we 264 obtained the standardized coefficients as effect sizes by re-fitting using standardized variables 265 that were scaled by the sample standard deviation and centered by sample mean values.

266 Additionally, when the effect of water temperature was detected, we tested the 267 relationship between mobile invertebrates and microalgal biomass which was omitted from the LMM because of the multi-collinearity with water temperature.

\section{RESULTS}

\section{Environmental factors}

Water temperature was lower at the four stations (BK, CL, CK and SR) near the channel than at 276 the other three stations in the inner parts of the estuary (HN, TB and SL) (Table 1). Salinity was 
277 lower at the lakeside stations $(\mathrm{BK}, \mathrm{HN}, \mathrm{TB}, \mathrm{SL}$ and $\mathrm{CK})$ that were influenced by freshwater

278 inputs. For these stations, the inter-annual variation was also higher as shown by data collected 279 by ourselves and other studies (Table 1).

280 Eelgrass biomass varied between 140 and $278 \mathrm{~g} \mathrm{DW} \mathrm{m}^{-2}$ among the stations. It was the

281 282 283

lowest at TB, followed by HN and BK (Table 1). Eelgrass shoot density ranged between 85 and 234 shoot $\mathrm{m}^{-2}$. It was highest at $\mathrm{BK}$ and second highest at $\mathrm{SL}$. The mean densities were not largely different among other stations. Microalgal biomass varied by more than ten-fold between the lowest station (SL) and the highest station (CL). In the latter, the microalgal biomass exceeded the biomass of the eelgrass. Macroalgae were not present at TB and SR. Branched red algae were dominated by Neosiphonia sp. and Chondria dasyphylla, and filamentous green algae were dominated by Cladophora sp. The mean biomass of red algae was highest at $\mathrm{HN}$ and that of green algae was highest at CL, although their biomasses were less than $15 \%$ that of eelgrass. Spirorbid polychaetes were not present at SL and CL. They were highly abundant at SR where their biomass was more than three-fold greater than the eelgrass biomass.

\section{Mobile invertebrate community}

A total of 32 mobile invertebrate species were collected in this study (Table S1). At taxonomic levels, polychaete worms made up $32.2 \%$ of the total biomass, followed by gastropods $(31.3 \%)$, gammarid amphipods (23.0\%), and isopods (8.8\%). At the species level, a polychaete Nereis sp. was most dominant (24.6\%), followed by gastropods Lacuna spp. (23.4\%) and the gammarid amphipod Ampithoe lacertosa (18.0\%). For an additional eight species including two gammarid amphipods (Monocorophium spp. and Pontogeneia rostrata), two isopods (Cymodoce japonica 
300

301

302

303

304

305

306

307

308

309

310

311

312

313

314

315

316

317

318

319

320

321

322

and Paranthura japonica), two gastropods (Ansola angustata and Siphonacmea oblongata) and two polychaetes (Exogone naidina and Syllis sp.), their proportions were less than 5\% at most.

The mean value of the total mobile invertebrate biomass was the highest at $\mathrm{CK}$ and much lower at stations along the coastline (HN, TB and SL). Species richness was the highest at CL, followed by $\mathrm{CK}$ and was approximately the same level at the other stations (Fig. 2). The mean value of species diversity was the highest at CL and the lowest at SR (Fig. 2).

\section{Population level analyses}

We found that each of the nine invertebrate populations belonging to gammaridae, gastropoda and polychaeta was predicted by a different combination of environmental factors in the optimal models (Table 2). The effect size of three epibionts on dominant invertebrate species was either similar or larger than abiotic and eelgrass factors (Fig. 3). For two isopods, no environmental factor correlated with their biomass.

Water temperature was selected as the responsible factor for the variation of A. lacertosa, Lacuna spp. and all three polychaetes. Among them, only Syllis sp. showed a significant correlation (positive). The significant effect of the salinity gradient was detected for $A$. angustata (negative) and S. oblongata (positive).

For the two predictors relevant to the characteristics of the eelgrass bed, the above-ground biomass showed a significantly positive relationship only with Syllis sp., whereas shoot density was significantly correlated with Monocorophium spp. (positive), P. rostrata (negative) and $E$. naidina (negative) (Table 2).

The biomasses of sessile epibionts (red algae, green algae and spirorbid polychaetes) on 
323 eelgrass blades were correlated with many invertebrate populations excluding A. lacertosa,

324 Monocorophium spp., two isopods and E. naidina in different manners. Red algal biomass was

325 positively correlated with $P$. rostrata, Lacuna spp. and Nereis sp., but negatively correlated with

326 Syllis sp. and tended to be negatively correlated with A. angustata. Green algal biomasses were

327 positively correlated with $P$. rostrate and Lacuna spp. The biomass of spirorbid polychaetes was

328 positively correlated with all three species of gastropods and was negatively correlated with 329 Syllis sp.

330 Although epiphytic microalgae were removed from our analysis because of the 331 collinearity with water temperature, no significant correlation was found for species that were 332 correlated with water temperature $($ A. lacertosa: Pearson's $\mathrm{r}=4.05, P=0.25 ;$ Lacuna $\mathrm{spp} .: \mathrm{r}=-$ 333 3.42, $P=0.69 ;$ E. naidina: $\mathrm{r}=0.31, P=0.92 ;$ Nereis $\mathrm{sp} .: \mathrm{r}=10.87, P=0.34 ;$ Syllis $\mathrm{sp} .: \mathrm{r}=0.21$, $334 P=0.86)$.

335

\section{Community level analyses}

The total invertebrate biomass tended to decrease with water temperature, and significantly increased with increasing eelgrass biomass and red algal biomass (Table 2). Species richness

340 showed a negative correlation with water temperature and spirorbid polychaetes. Species

341 diversity was positively correlated with green algal biomass, but was negatively correlated with 342 spirorbid polychaetes (Table 2). The effect size of red algal biomass on the total invertebrate 343 biomass was similar to that of eelgrass biomass, and that of spirorbid polychaetes on species richness was also similar to that of water temperature (Fig. 3). 


\section{DISCUSSION}

The present study demonstrated that the biomass gradient of epibiotic organisms (e.g. macroalgae and spirorbid polychaetes) was a good predictor of the variation in some dominant

351

352 mobile invertebrates in the eelgrass bed and the population biomass of the community parameters such as total biomass and diversity. Further, we found that the population biomasses and community components were not always influenced only by a single factor but also by multiple factors. The effect of the macroalgae is notable because these sessile epibionts have a much lower biomass compared to the biomass of eelgrass and epiphytic microalgae. However, the observed relationships between these functional groups and mobile invertebrate populations varied greatly among the species.

In the optimal models, the effects of biomass of epibiotic organisms on the gammarid amphipod $P$. rostrata, all three gastropod species (A. angustata, Lacuna sp. and $S$. oblongata) and two polychaetes (Nereis sp. and Syllis sp.) were detected. For those species, the sessile epibionts were positively related to mobile invertebrate biomasses except for Syllis sp. and $P$. rostrata, which showed a positive correlation with both red and green algae. The algae are considered to be used as a temporal shelter (habitat) rather than as a food resource because these animals do not firmly attach to the eelgrass blades but rather drift among shoots (Suh \& Yu, 1997; Yamada et al., 2007b; Yu, Jeong \& Suh, 2008), and because they have a preference for feeding on phytoplankton and detritus (Yu \& Suh, 2011). High predation risk for swimming amphipods with low self-defense abilities, such as $P$. rostrata, has been reported in several studies (Sudo \& Azeta, 1992; Beare \& Moore, 1998). In fact, gammarid amphipods are a major 
369 source of prey for blennoid fish in the eelgrass beds of Northern Japan (Watanabe et al., 1996;

370 Sawamura, 1999; Yamada et al., 2010). Therefore, the complex micro-habitat created by

371 macroalgae allows them to escape these predators.

372 All three gastropods increased in correlation with spirorbid polychaetes, whereas the

373

374

375

376

377

378

379

380

381

382

383

384

385

386

387

388

389

390

391

responses to the other factors were different (Table 2). Because the gastropods adhere to flat seagrass blades, the flat (simple) structure created by seagrass blades can be better than the rough structure of spirorbid polychaetes. Therefore, competition for space (negative effect) appears to be more expected than facilitation. Although we do not have a good answer for the positive relationships, one possibility for this unexpected result is that the rough structure acts as a shelter because small-sized individuals $(<3 \mathrm{~mm})$ are frequent in gastropod populations during the summer season (A. angustata: Momota, personal observation; Lacuna spp.: Kanamori, Goshima \& Mukai, 2004; S. oblongata: Toyohara, Nakaoka \& Tsuchida, 2001).

Red algae are considered to positively affect Nereis sp. by providing habitat because polychaetes build tubes both on eelgrass blades and in red algal canopies in Akkeshi (Momota, unpublished data). The negative effect of red algae and spirorbid polychaetes on Syllis sp. may suggest that this mobile polychaete prefers a simple structured habitat without a complex microhabitat created by eelgrass blades with sessile epibionts.

In addition to the effects of sessile epibionts, the significant effects of water temperature, salinity, eelgrass biomass and shoot density were detected for a majority of the dominant species, although the patterns and directions of the effects were different among them. Surprisingly, eelgrass biomass was not correlated with most species except for Syllis sp., and the direction (positive/negative) of the effect of eelgrass shoot density was different among the species. The same response of syllid polychaetes was reported in previous studies (e.g. Bone \& San Martín, 
392 2003). For eelgrass shoot density, the result suggests that it indirectly affects mobile

393 invertebrates through interfering with multiple physical and biological processes (e.g. water

394 current and flux, detritus and drifting algae trapping, recruitment, and predation intensity: Gambi,

395 Nowell \& Jumars, 1990; Robbins \& Bell, 1994; Attrill, Strong \& Rowden 2000; Boström \&

396 Bonsdorff, 2000; Lee, Fong \& Wu, 2001; Hovel et al., 2002). Notably, the contrasting

397 relationships of $P$. rostrate with eelgrass shoot density and macroalgae imply that the shelter

398 effect is different depending on the spatial scale (i.e. blade scale, shoot/patch scale).

The isopods $C$. japonica and $P$. japonica were not correlated with any abiotic or biotic

400 factors because of the low dependency on the seagrass habitat; they can utilize other numerous

401 habitats created by both natural and artificial materials (e.g. mussel beds, oyster reefs: Marchini

402 et al., [2014]; Nakamachi, Ishida \& Hirohashi, [2015]; gravel, litter layer of macrophytes,

403 Sargassum meadow: Momota, personal observation). Additionally, their uniform appearance

404 throughout all of the stations indicates that they have a wide tolerance to a broad range of

405 environmental stress, which leads to a lack of correlation with any of the abiotic factors.

406 Additionally, the gammarid amphipod A. lacertosa was not significantly correlated with any

407 factors. This species is widely distributed along the Pacific-rim coast of the northern hemisphere

408 and utilizes a variety of plant habitats by building tubes (Hiebert, 2013), which may explain why

409 it did not show any relationship with the environmental gradients.

410 Although the discussion on underlying drivers that generate apparent correlations (i.e. the

411 causalities) between epibionts and mobile invertebrates is not our main focus, the indirect effects

412 and the top-down control of mobile invertebrates should also be taken into account to interpret

413 present findings. For example, we can give an alternative possibility for the positive relationship

414 between gastropods and spirorbid polychaetes such that high grazing of the gastropods facilitates 
415 the recruitment of spirorbid polychaetes through the removal of the microalgal cover.

416 Total biomass, species richness and species diversity were differentially correlated with

417 abiotic/biotic factors, and varied in a complex manner although processes were unclear. The

418 optimal model of the three community variables contains one or two variables of sessile

419 epibionts. The positive correlation of red algae with total biomass reflects that with highly

420 dominant species, such as Lacuna spp. and Nereis sp., which occupied more than $48 \%$ of the

421 total biomass. The negative interaction of spirorbid polychaetes with species richness and

422 diversity suggest that spirorbid polychaetes can decrease the homogeneity of the biomasses of

423 component species within a community by allowing some competitive species to dominate. The

424 effect of green algae was found only on species evenness, but not on total biomass nor on species

425 richness, suggesting that the green algae may increase species evenness by decreasing abundance

426 of dominant species although the actual mechanisms remain to be cleared.

427

428

429 CONCLUSIONS

430

431

The present study suggests that macroalgae and sessile animals on eelgrass blades can affect the biomass and diversity of mobile invertebrates and that incorporating these biotic factors can improve the prediction of the variability of the mobile invertebrate community in the eelgrass bed. However, the underlying causal relationships appear to be complex and vary greatly from species to species. Our findings were based on data collected over one sampling period when the eelgrass bed was most productive and when the abundance and/or diversity of algae and mobile invertebrates typically reached their maximum. A more comprehensive investigation of the 
438 functional relationships among the various types of organisms and of the temporal changes

439 should be conducted in future studies on eelgrass bed communities.

440 Recent studies demonstrated that the capacity for resistance and resilience to 441 environmental stress and perturbations vary with food web structure in seagrass beds, which 442 knowledge can contribute to improvement of coastal management (Unsworth et al., 2015; 443 Maxwell et al., 2016; Östman et al., 2016). Our study comparing population and community 444 level responses of epifauna to different types of epibionts on eelgrass blades adds more 445 knowledge on the complex trophic/non-trophic interactions of eelgrass communities, and will 446 promote more understandings of the resilience and the feedback mechanisms of seagrass 447 ecosystems which offer variable ecosystem services to human such as seafood provisioning and 448 water quality controls (Cullen-Unsworth et al., 2013; Nordlund et al., 2016).

ACKNOWLEDGEMENTS and Environment of Inland Sea, and T. Maezawa in Hokkaido University.

REFERENCES

Attrill MJ, Strong JA, Rowden AA. 2000. Are macroinvertebrate communities influenced by 
461

462

463

464

465

466

467

468

469

470

471

472

473

474

475

476

477

478

479

480

481

482

483

seagrass structural complexity? Ecography 23:114-121 DOI 10.1111/j.16000587.2000.tb00266.x.

Bates D, Maechler M, Bolker B, Walker S. 2014. lme4: linear mixed-effects models using Eigen and S4. http: //CRAN.R-project.org/package=lme4

Beare DJ, Moore PG. 1998. Aspects of the life histories of Perioculodes longimanus, Pontocrates arcticus and Synchelidium maculatum (Crustacea: Amphipoda) at Millport, Scotland. Journal of the Marine Biological Association of the United Kingdom 78:193-209 DOI $10.1017 /$ S0025315400040029.

Blake RE, Duffy JE. 2010. Grazer diversity affects resistance to multiple stressors in an experimental seagrass ecosystem. Oikos 119:1625-1635 DOI 10.1111/j.16000706.2010.18419.x.

Bolker BM, Brooks ME, Clark CJ, Geange SW, Poulsen JR, Stevens MHH, White JSS. 2009. Generalized linear mixed models: a practical guide for ecology and evolution. Trends in ecology and evolution 24:127-135 DOI 10.1016/j.tree.2008.10.008

Bolker BM, R Development Core Team. 2013. bbmle: tools for general maximum likelihood estimation. http://CRAN.R-project.org/package $=$ bbmle.

Bone D, San Martín G. 2003. Ecological aspects of syllids (Annelida: Polychaeta: Syllidae) on Thalassia testudinum beds in Venezuela. Hydrobiologia 496:289-298 DOI 10.1023/A:1026117503709.

Boström C, Bonsdorff E. 2000. Zoobenthic community establishment and habitat complexity The importance of seagrass shoot-density, morphology and physical disturbance for faunal recruitment. Marine Ecology Progress Series 205:123-138 DOI 10.3354/meps205123.

Burnham KP, Anderson DR. 2002. Model selection and multimodel inference: a practical 
484

485

486

487

Information-Theoretic approach. New York: Springer.

Carlton JT, ed. 2007. The Light and Smith manual: intertidal invertebrates from Central California to Oregon, $4^{\text {th }}$ edition. Berkeley, CA: University of California Press. ISBN 9780520239395.

Cullen-Unsworth LC, Nordlund LM, Paddock J, Baker S, McKenzie LJ, Unsworth RKF. 2014. Seagrass meadows globally as a coupled social-ecological system: Implications for human wellbeing. Marine pollution bulletin 83:387-397 DOI 10.1016/j.marpolbul.2013.06.001.

Dormann CF, Elith J, Bacher S, Buchmann C, Carl G, Carré G, Marquéz JRG, Gruber B, Lafourcade B, Leitão PJ, Münkemüller T, Mcclean C, Osborne PE, Reineking B, Schröder B, Skidmore AK, Zurell D, Lautenbach S. 2013. Collinearity: A review of methods to deal with it and a simulation study evaluating their performance. Ecography 36:27-46 DOI 10.1111/j.1600-0587.2012.07348.x.

Duffy JE. 2006. Biodiversity and the functioning of seagrass ecosystems. Marine Ecology Progress Series 311:233-250 DOI 10.3354/meps311233.

Duffy JE, Hay ME. 2000. Strong impacts of grazing amphipods on the organization of a benthic community. Ecological Monographs 70:237-263 DOI 10.1890/00129615(2000)070[0237:SIOGAO]2.0.CO;2.

Duffy JE, Richardson JP, France KE. 2005. Ecosystem consequences of diversity depend on food chain length in estuarine vegetation. Ecology Letters 8:301-309 DOI 10.1111/j.14610248.2005.00725.x.

Douglass JG, France KE, Richardson JP, Duffy JE. 2010. Seasonal and interannual change in a Chesapeake Bay eelgrass community: Insights into biotic and abiotic control of 

10.4319/lo.2010.55.4.1499.

Edgar GJ. 1990. The use of the size structure of benthic macrofaunal communities to estimate faunal biomass and secondary production. Journal of Experimental Marine Biology and Ecology 137:195-214 DOI 10.1016/0022-0981(90)90185-F.

Gambi MC, Nowell ARM, Jumars PA. 1990. Flume observations on flow dynamics in Zostera marina (eelgrass) beds. Marine Ecology Progress Series 61:159-169 DOI $10.3354 /$ meps061159.

Gartner A, Tuya F, Lavery PS, McMahon K. 2013. Habitat preferences of macroinvertebrate fauna among seagrasses with varying structural forms. Journal of Experimental Marine Biology and Ecology 439:143-151 DOI 10.1016/j.jembe.2012.11.009.

Hamamoto K., Mukai H. 1999. Effects of larval settlement and post-settlement mortality on the distribution pattern and abundance of the spirorbid tube worm Neodexiospira brasiliensis (Grube) (Polychaeta) living on seagrass leaves. Marine Ecology 20:251-272 DOI 10.1046/j.1439-0485.1999.2034075.x.

Harley CDG. 2006. Effects of physical ecosystem engineering and herbivory on intertidal community structure. Marine Ecology Progress Series 317:29-39 DOI 10.3354/meps317029.

\section{Harley CDG, Hughes AR, Hulgren KM, Miner BG, Sorte CJB, Thornber CS, Rodriguez} LF, Tomanek L, Williams SL. 2006. The impacts of climate change in coastal marine systems. Ecology Letters 9:228-241 DOI 10.1111/j.1461-0248.2005.00871.x.

Hasegawa N, Hori M, Mukai H. 2007. Seasonal shifts in seagrass bed primary producers in a cold-temperate estuary: Dynamics of eelgrass Zostera marina and associated epiphytic algae. Aquatic Botany 86:337-345 DOI 10.1016/j.aquabot.2006.12.002. 
530 Heck Jr KL, Hays G, Orth RJ. 2003. Critical evaluation of nursery hypothesis for seagrasses.

531 Marine Ecology Progress Series 253:123-136 DOI 10.3354/meps253123.

532 Heck Jr KL, Pennock JR, Valentine JF, Coen LD, Sklenar SA. 2000. Effects of nutrient 533 enrichment and small predator density on seagrass ecosystems: An experimental assessment. 534 Limnology and Oceanography 45:1041-1057 DOI 10.4319/1o.2000.45.5.1041.

535

536

Heck Jr KL, Valentine JF 2006. Plant-herbivore interactions in seagrass meadows. Journal of Experimental Marine Biology and Ecology 330:420-436 DOI 10.1016/j.jembe.2005.12.044.

Hemminga MA, Duarte CM. 2000. Seagrass Ecology. Cambridge: Cambridge University Press.

Hiebert, TC. 2015. Ampithoe lacertosa. In: Hiebert TC, Butler BA, Shanks AL, eds. Oregon Estuarine Invertebrates: Rudys' Illustrated Guide to Common Species, $3^{\text {rd }}$ edition. Charleston, OR: University of Oregon Libraries and Oregon Institute of Marine Biology.

Hoegh-Guldberg O, Bruno JF. 2010. The impact of climate change on the world's marine ecosystems. Science 328:1523-1528 DOI 10.1126/science.1189930 .

Hovel KA, Fonseca MS, Myer DL, Kenworthy WJ, Whitfield PE. 2002. Effects of seagrass landscape structure, structural complexity and hydrodynamic regime on macrofaunal densities in North Carolina seagrass beds. Marine Ecology Progress Series 243:11-24 DOI $10.3354 /$ meps 243011 .

Hughes AR, Williams SL, Duarte CM, Heck KL, Waycott M. 2009. Associations of concern: Declining seagrasses and threatened dependent species. Frontiers in Ecology and Evolution 7:242-246 DOI 10.1890/080041.

Iizumi H, Taguchi S, Minami T, Mukai H, Maekawa S. 1996. Distribution and variability of nutrients, chlorophyll a, particulate organic matters, and their carbon and nitrogen contents, in Akkeshi-ko, an estuary in northern Japan. Bulletin of the Hokkaido National Fisheries 
Research Institute 59:43-67.

554

555

556

557

558

559

560

561

562

563

564

565

566

567

568

569

570

571

572

573

574

575

Imajima M, ed. 1996. Polychaetous Annelids. Tokyo: AQUABIOLOGY. ISBN 9784915342103.

Imajima M, ed. 2001. Polychaetous Annelids II. Tokyo: AQUABIOLOGY. ISBN 9784915342257.

Jernakoff P, Brearley A, Nielsen J. 1996. Factors affecting grazer-epiphyte interactions in temperate seagrass meadows. Oceanography and Marine Biology: An Annual Review 34:109-162.

Kanamori M, Goshima S, Mukai H. 2004. Seasonal variation in host utilization of epiphytic Lacuna species in mixed algal and surfgrass stands in Japan. Marine Ecology 25:51-69 DOI 10.1111/j.1439-0485.2004.00014.x.

Kasim M, Mukai H. 2006. Contribution of benthic and epiphytic diatoms to clam and oyster production in the Akkeshi-ko estuary. Journal of Oceanography 62:267-281 DOI 10.1007/s10872-006-0051-9.

Kuznetsova A, Brockhoff PB, Christensen RHB. 2014. lmerTest: Tests for random and fixed effects for linear mixed effect models (lmer objects of lme4 package). R package version $2.0-11$.

Lee SY, Fong CW, Wu RSS. 2001. The effects of seagrass (Zostera japonica) canopy structure on associated fauna: a study using artificial seagrass units and sampling of natural beds. Journal of Experimental Marine Biology and Ecology 259:23-50 DOI 10.1016/S00220981(01)00221-0.

Lefcheck JS, van Montfrans J, Orth RJ, Schmitt EL, Duffy JE, Luckenbach MW. 2014. Epifaunal invertebrates as predators of juvenile bay scallops (Argopecten irradians). 

10.1016/j.jembe.2014.01.014.

Long HA, Grosholz ED. 2015. Overgrowth of eelgrass by the invasive colonial tunicate Didemnum vexillum: Consequences for tunicate and eelgrass growth and epifauna abundance. Journal of Experimental Marine Biology and Ecology 473:188-194 DOI 10.1016/j.jembe.2015.08.014

Marchini A, Sorbe J, Torelli F, LodolaA. 2014 The non-indigenous Paranthura japonica Richardson, 1909 in the Mediterranean Sea: travelling with shellfish? Mediterranean Marine Science. 15:545-553 DOI 10.12681/mms.779.

Maxwell PS, Eklöf JS, van Katwijk MM, O'Brien KR, de la Torre-Castro M, Boström C, Bouma T, Krause-Jensen D, Unsworth RKF, van Tussenbroek B, van der Heide T. 2016. The fundamental role of ecological feedback mechanisms in seagrass ecosystems - a review. Biological Reviews DOI 10.1111/brv.12294.

Meager JJ, Schlacher TA, Green M. 2011. Topographic complexity and landscape temperature patterns create a dynamic habitat structure on a rocky intertidal shore. Marine Ecology Progress Series 428:1-12 DOI 10.3354/meps09124.

Nakamachi T, Ishida H, Hirohashi N. 2015. Sound Production in the Aquatic Isopod Cymodoce japonica (Crustacea: Peracarida). The Biological Bulletin 229:167-172 DOI 10.1086/BBLv229n2p167.

Nishimura S, ed. 1992. Guide to seashore animals of Japan with color pictures and keys, vol 1(in Japanese). Osaka: Hoikusha. ISBN 978-4586302017.

Nishimura S, ed. 1995. Guide to seashore animals of Japan with color pictures and keys, vol 2(in Japanese). Osaka: Hoikusha. ISBN 978-4586302024. 
599 Nordlund LM, Koch EW, Barbier EB, Creed JC. 2016. Seagrass Ecosystem Services and

600 Their Variability across Genera and Geographical Regions. PloS one 11: e0163091 DOI $601 \quad$ 10.1371/journal.pone.0163091.

602 Ogawa H, ed. 2011. A Guidebook of Gammarids in Tokyo Bay. Open edition ver.1.2. Toho 603 University, Japan: Furota Lab, Laboratory of Environmental Ecology, Department of 604 Environmental Science, Faculty of Science.

605 Okutani T, ed. 2000. Marine Mollusks in Japan. Tokyo: University of Tokyo Press.

606 Östman Ö, Eklöf J, Eriksson BK, Olsson J, Moksnes PO, Bergström U. 2016. Top - down

Poore AGB, Campbell AH, Coleman RA, Edgar GJ, Jormalainen V, Reynolds PL, Sotka EE, Stachowicz JJ, Taylor RB, Vanderklift MA, Duffy JE. 2012. Global patterns in the impact of marine herbivores on benthic primary producers. Ecology Letters 15:912-922 DOI 10.1111/j.1461-0248.2012.01804.x.

R Development Core Team 2015. R: A language and environment for statistical computing. Vienna, Austria: R Foundation for Statistical Computing.

Robbins BD, Bell SS. 1994. Seagrass landscapes: A terrestrial approach to the marine subtidal environment. Trends in Ecology and Evolution 9:301-304 DOI 10.1016/01695347(94)90041-8.

Sawamura M. 1999 One-year Comparison of Stomach Contents among Demersal Fishes off the Coast of Usujiri, Hokkaido (in Japanese with English abstract). Japanese Journal of Benthology 54:14-23. 
622 Somero GN. 2002. Thermal physiology and vertical zonation of intertidal animals: optima,

623

624

625

626

627

628

629

630

631

632

633

634

635

636

637

638

639

640

641

642

643

644

limits, and costs of living. Integrative and Comparative Biology 42:780-789 DOI 10.1093/icb/42.4.780.

Sudo H, Azeta M. 1992. Selective predation on mature male Byblis japonicas (Amphipoda: Gammaridea) by the barface cardinalfish, Apogon semilineatus. Marine Biology 114:211217 DOI 10.1007/BF00349521.

Suh HL, Yu OH. 1997. Winter zonation of the benthic amphipods in the sandy shore surf zone of Dolsando, southern Korea (in Korean with English abstract). Korean Journal of Fisheries and Aquatic Sciences 30:340-348.

Thomsen MS. 2010. Experimental evidence for positive effects of invasive seaweed on native invertebrates via habitat-formation in a seagrass bed. Aquatic Invasions 5:341-346 DOI 10.3391/ai.2010.5.4.02.

Toyohara T, Nakaoka M, Tsuchida E. 2001. Population dynamics and life history traits of Siphonacmea oblongata Yokohama on seagrass leaf in Otsuchi Bay (Siphonariidae, Pulamonata). Venus (Jap. J. Malaco) 60:27-36.

Unsworth RKF, Collier CJ, Waycott M, Mckenzie LJ, Cullen-Unsworth LC. 2015. A framework for the resilience of seagrass ecosystems. Marine pollution bulletin, 100:34-46 DOI 10.1016/j.marpolbul.2015.08.016.

Valentine JF, Duffy JE. 2006. The Central Role of Grazing in Seagrass Ecology. In: Larkum AWD, Orth RJ, Duarte CM, eds. Seagrasses: Biology, Ecology, and Conservation. Springer, 463-501.

Valentine JF, Heck Jr KL. 1999. Seagrass herbivory: Evidence for the continued grazing of marine grasses. Marine Ecology Progress Series 176:291-302 DOI 10.3354/meps176291. 
645 Watanabe K, Minami T, Iizumi H, Imamura S. 1996. Interspecific relationship by 646 composition of stomach contents of fish at Akkeshi-ko, an estuary at eastern Hokkaido, 647 Japan (in Japanese with English abstract). Bulletin of the Hokkaido National Fisheries $648 \quad$ Research Institute 60:239-276

649

650

651

652

653

654

655

656

657

658

659

660

661

662

663

664

665

666

667

Watanabe M, Nakaoka M, Mukai H. 2005. Seasonal variation in vegetative growth and production of the endemic Japanese seagrass Zostera asiatica: A comparison with sympatric Zostera marina. Botanica Marina 48:266-273 DOI 10.1515/BOT.2005.036.

Whalen MA, Duffy JE, Grace JB. 2013. Temporal shifts in top-down vs. bottom-up control of epiphytic algae in a seagrass ecosystem. Ecology 94:510-520 DOI 10.1890/12-0156.1.

Yamada K, Hori M, Tanaka Y, Hasegawa N, Nakaoka M. 2007b. Temporal and spatial macrofaunal community changes along a salinity gradient in seagrass meadows of Akkeshiko estuary and Akkeshi Bay, northern Japan. Hydrobiologia, 592, 345-358 DOI 10.1007/s10750-007-0767-6.

Yamada K, Hori M, Tanaka Y, Hasegawa N, Nakaoka M. 2010. Contribution of different functional groups to the diet of major predatory fishes at a seagrass meadow in northeastern Japan. Estuarine, Coastal and Shelf Science 86:71-82 DOI 10.1016/j.ecss.2009.10.015.

Yamada K, Takahashi K, Vallet C, Taguchi S, Toda T. 2007a. Distribution, life history, and production of three species of Neomysis in Akkeshi-ko estuary, northern Japan. Marine Biology 150:905-917 doi:10.1007/s00227-006-0403-4.

Ysebaert T, Herman PMJ, Meire P, Craeymeersch J, Verbeek H, Heip CHR. 2003. Largescale spatial patterns in estuaries: Estuarine macrobenthic communities in the Schelde estuary, NW Europe. Estuarine, Coastal and Shelf Science 57:335-355 DOI 10.1016/S0272-7714(02)00359-1. 
668 Yu OH, Jeong SJ, Suh HL. 2008. Reproductive Pattern of the Epifaunal Amphipod 669 Pontogeneia rostrata (Crustacea) on Dolsando Sandy Shore in Korea. Ocean Science $670 \quad$ Journal 43:127-133 DOI 10.1007/BF03020693.

671 Yu OH, Suh HL. 2011. Secondary production of the eusirid amphipod Pontogeneia rostrata 672 Gurjanova, 1938 (Crustacea: Peracarida) on a sandy shore in Korea. Ocean Science Journal $673 \quad$ 46:211-217 DOI 10.1007/s12601-011-0017-8.

674 Zuur AF, Ieno EN, Walker N, Saveliev AA, Smith GM. 2009. Mixed effects models and 675 extensions in ecology with $R$. New York, USA: Springer.

676

677

678

679

680

681

682

683

684

685

686

687

688

689

690 
691

692

693

694

695

696

697

698

699

700

701

702

703

704

705

710

711

712

713

\section{List of figures}

Fig. 1. Location of the study sites in the Akkeshi-ko estuary and the Akkeshi Bay in Northeastern Japan. The area enclosed by a dashed circle is the Akkeshi-ko estuary. Most of the clam aquaculture grounds are located in the western part of the estuary (indicated by a dotted circle).

Fig. 2. (A) The total invertebrate biomass, (B) species richness and (C) Shannon-Wiener diversity index at the seven stations in the Akkeshi-ko estuary and Akkeshi Bay. The bars indicate the mean values with SDs. The order of the stations is lined up based on relative size of the impact of freshwater inflow or seawater from Akkeshi Bay.

Fig. 3. Effect size of abiotic and biotic factors on mobile invertebrate populations and community detected by linear mixed models. Water temperature (WT), salinity (Sal), eelgrass biomass (ZM.bm), eelgrass shoot density (ZM.den), branched red algae (Red.alg), filamentous green algae (Grn.alg)and spirorbid polychaetes (SP.bm). We only reported the results of predictors selected by the best models (Table 2). Open circles represent detected predictors without significance $(P>0.05)$ and filled circles represent detected predictors with significance $(P<0.05)$. Error bars indicate standard errors of effect sizes. 






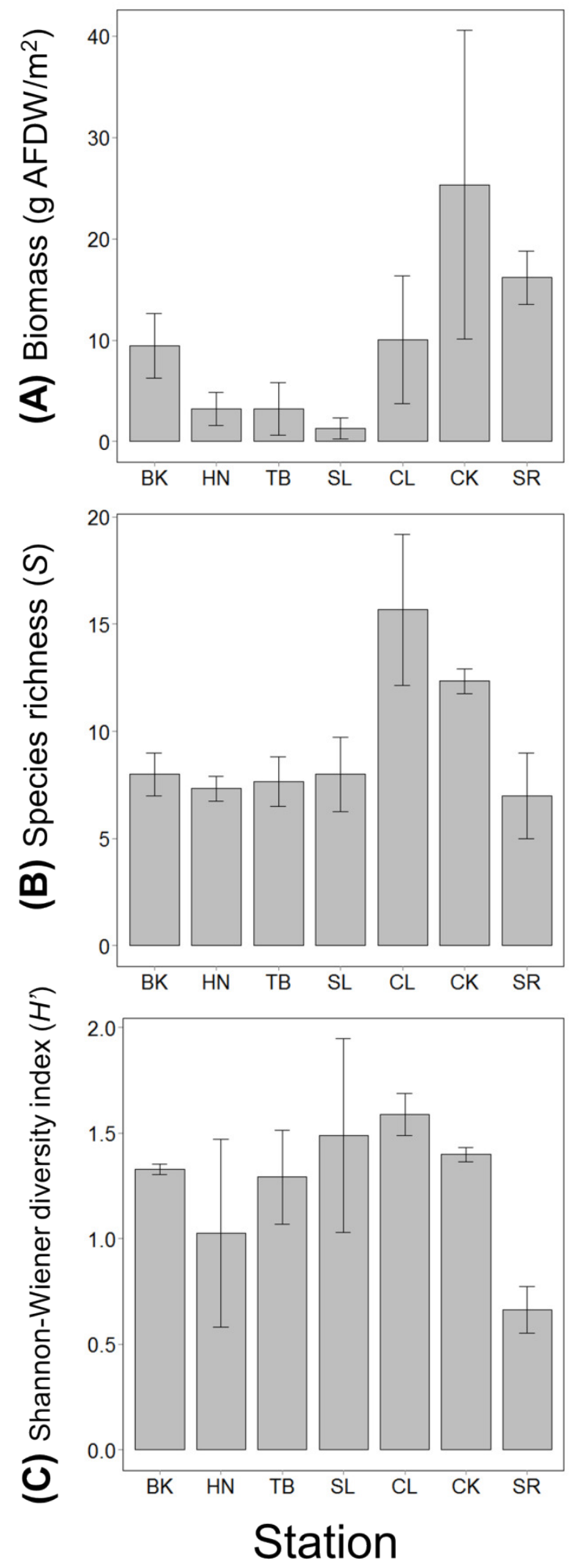

Fig. 2. Momota \& Nakaoka 

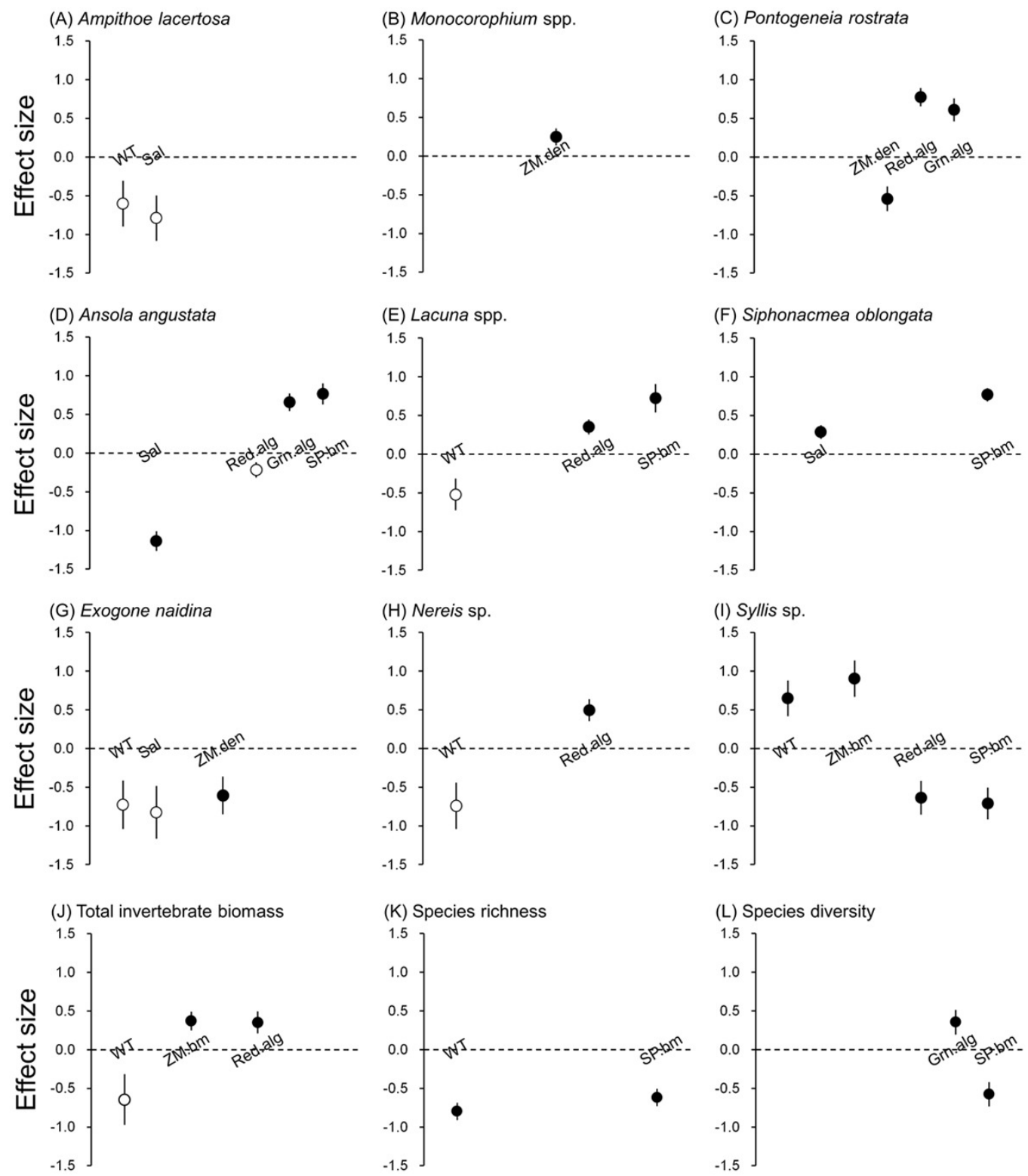
Table

731

Table 1. Environmental conditions at seven stations in the Akkeshi-ko estuary and Akkeshi Bay. Abiotic factors in this study are indicated by boldface. For water temperature and salinity, we also presented data in August reported by the other studies.

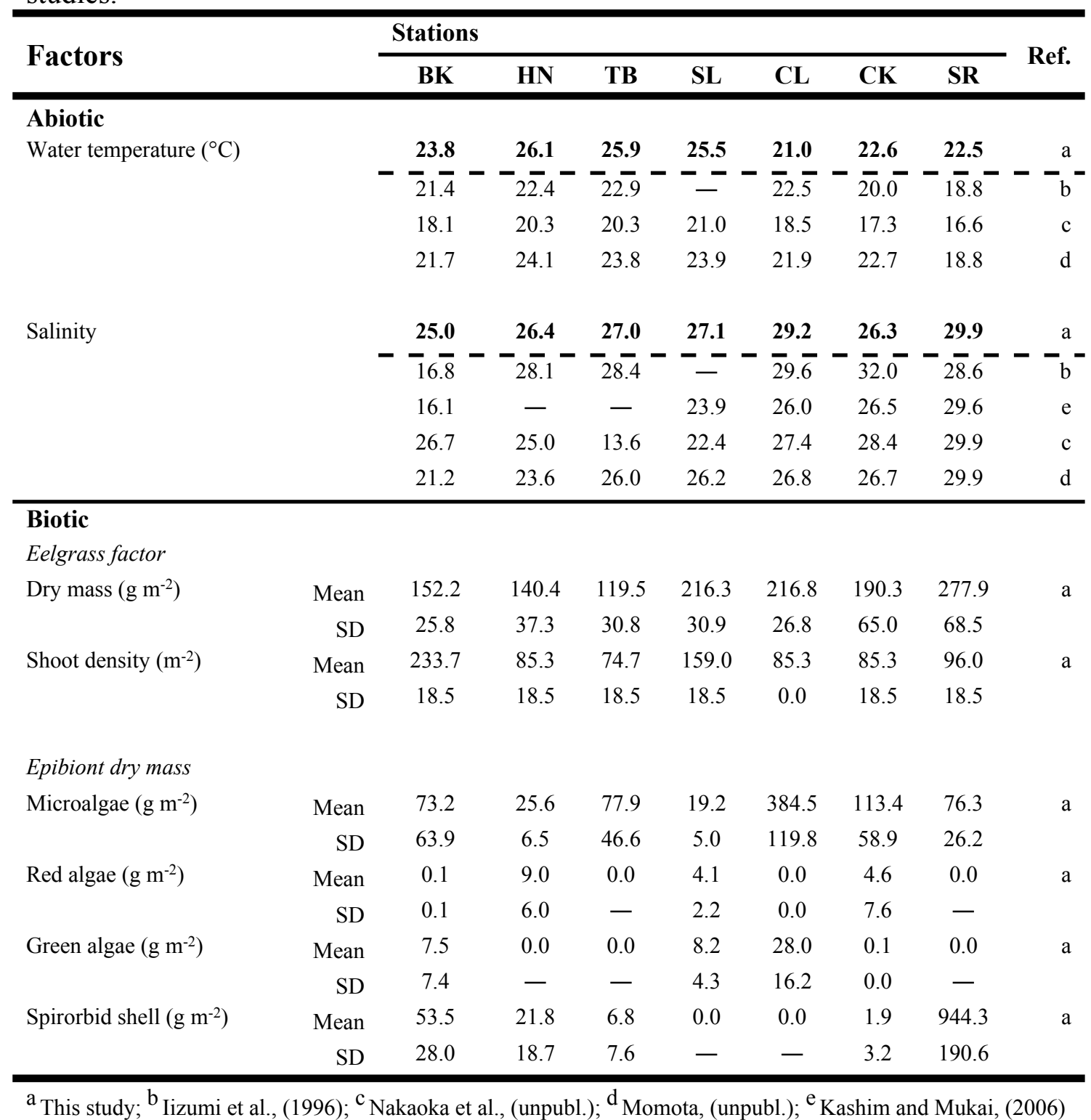


Table 2. Results of LMMs for explaining responsible environmental factors on variation in mobile invertebrate populations and community components. $\mathrm{AIC}_{\mathrm{c}}$ scores and delta $\mathrm{AIC}_{\mathrm{c}}$ are also reported. Significant coefficients $(P$-values $<0.05$ level $)$ and the lowest $\mathrm{AIC}_{\mathrm{c}}$ scores are in bold face. Standardized coefficients (Std.coef) of the optimal models are reported right below each optimal model in italic face. Abbreviations as follows; WT: water temperature, Sal: salinity, ZM.bm: eelgrass biomass, ZM.den: eelgrass shoot density, Red.alg: red algal biomass, Grn.alg: green algal biomass, SP.bm: spirorbid polychaete biomass.

\begin{tabular}{|c|c|c|c|c|c|c|c|c|c|c|c|}
\hline \multirow{2}{*}{ Response } & \multirow{2}{*}{ Model } & \multicolumn{8}{|l|}{ Predictor } & \multirow{2}{*}{$\mathrm{AIC}_{\mathbf{c}}$} & \multirow{2}{*}{$\Delta \mathrm{AIC}_{\mathrm{c}}$} \\
\hline & & (Intercept) & WT & Sal & ZM.bm & ZM.den & Red.alg & Grn.alg & SP.bm & & \\
\hline \multicolumn{12}{|l|}{ Population } \\
\hline \multicolumn{12}{|l|}{ Gammarid amphipoda } \\
\hline \multirow[t]{3}{*}{ Ampithoe lacertosa } & Null & 33.978 & - & - & - & - & - & - & - & 193.9 & 1.0 \\
\hline & Full & 673.282 & -87.465 & -48.498 & -0.482 & 4.427 & 7.243 & -0.761 & -0.736 & 216.7 & 23.8 \\
\hline & Optimal & 1097.930 & -79.180 & -129.700 & & & & & & 192.9 & - \\
\hline \multirow[t]{3}{*}{ Monocorophium spp. } & Null & 8.669 & - & - & - & - & - & - & - & 137.7 & 2.0 \\
\hline & Full & 582.409 & -42.288 & -72.767 & 0.079 & 0.986 & 0.265 & 0.428 & 0.059 & 160.1 & 24.4 \\
\hline & Optimal & -6.824 & & & & 1.469 & & & & 135.7 & - \\
\hline \multirow[t]{3}{*}{ Pontogeneia rostrata } & Null & 10.068 & - & - & - & - & - & - & - & 147.2 & 19.8 \\
\hline & Full & 247.381 & -11.576 & -32.023 & 0.407 & -2.751 & 4.934 & 2.878 & 0.111 & 139.5 & 12.1 \\
\hline & Optimal & 20.728 & & & & -1.842 & 5.023 & 2.523 & & 127.4 & - \\
\hline
\end{tabular}


Table 2. (continued 1)

\begin{tabular}{|c|c|c|c|c|c|c|c|c|c|c|c|}
\hline \multirow{2}{*}{ Response } & \multirow{2}{*}{ Model } & \multicolumn{8}{|l|}{ Predictor } & \multirow{2}{*}{$\mathbf{A I C}_{\mathbf{c}}$} & \multirow{2}{*}{$\Delta \mathrm{AIC}_{\mathrm{c}}$} \\
\hline & & (Intercept) & WT & Sal & ZM.bm & ZM.den & Red.alg & Grn.alg & SP.bm & & \\
\hline \multicolumn{12}{|l|}{ Isopoda } \\
\hline \multirow[t]{3}{*}{ Cymodoce japonica } & Null & 11.630 & - & - & - & - & - & - & - & 187.0 & 0.0 \\
\hline & Full & 605.245 & -15.501 & -100.306 & 4.532 & -5.585 & 0.308 & 2.552 & -0.113 & 211.1 & 24.1 \\
\hline & Optimal & 11.630 & & & & & & & & 187.0 & - \\
\hline \multirow[t]{3}{*}{ Paranthura japonica } & Null & 14.077 & - & - & - & - & - & - & - & 173.4 & 0.0 \\
\hline & Full & 132.132 & 8.691 & -32.148 & 0.349 & -0.924 & 2.623 & 4.411 & 0.463 & 200.0 & 26.6 \\
\hline & Optimal & 14.077 & & & & & & & & 173.4 & - \\
\hline \multicolumn{12}{|l|}{ Gastropoda } \\
\hline \multirow[t]{3}{*}{ Ansola angustata } & Null & 6.014 & - & - & - & - & - & - & - & 159.6 & 10.1 \\
\hline & Full & 555.710 & -12.507 & -96.596 & -0.524 & 1.180 & -1.487 & 3.730 & 0.923 & 167.3 & 17.8 \\
\hline & Optimal & 600.167 & & -116.259 & & & -2.645 & 5.102 & 1.149 & 149.5 & - \\
\hline \multirow[t]{3}{*}{ Lacuna spp. } & Null & 28.820 & - & - & - & - & - & - & - & 197.0 & 11.2 \\
\hline & Full & 880.106 & -129.988 & -43.910 & 0.940 & -2.094 & 10.442 & -2.761 & 2.607 & 203.9 & 18.1 \\
\hline & Optimal & 522.161 & -106.591 & & & & 10.634 & & 2.696 & 185.8 & - \\
\hline \multirow[t]{3}{*}{ Siphonacmea oblongata } & Null & 8.003 & - & - & - & - & - & - & - & 166.6 & 17.2 \\
\hline & Full & -350.288 & -16.668 & 82.450 & -1.654 & 2.567 & 1.664 & -2.471 & 1.063 & 172.7 & 23.3 \\
\hline & Optimal & -190.996 & & 36.374 & & & & & 1.426 & 149.4 & 一 \\
\hline
\end{tabular}


Table 2. (continued 2)

\begin{tabular}{|c|c|c|c|c|c|c|c|c|c|c|c|}
\hline \multirow{2}{*}{ Response } & \multirow{2}{*}{ Model } & \multicolumn{8}{|l|}{ Predictor } & \multirow{2}{*}{$\mathrm{AIC}_{\mathrm{c}}$} & \multirow{2}{*}{$\Delta \mathbf{A I C}_{\mathrm{c}}$} \\
\hline & & (Intercept) & WT & Sal & ZM.bm & ZM.den & Red.alg & Grn.alg & SP.bm & & \\
\hline \multirow[t]{3}{*}{ Siphonacmea oblongata } & Null & 8.003 & - & - & - & - & - & - & - & 166.6 & 17.2 \\
\hline & Full & -350.288 & -16.668 & 82.450 & -1.654 & 2.567 & 1.664 & -2.471 & 1.063 & 172.7 & 23.3 \\
\hline & Optimal & -190.996 & & 36.374 & & & & & 1.426 & 149.4 & - \\
\hline \multicolumn{12}{|l|}{ Polychaeta } \\
\hline \multirow[t]{3}{*}{ Exogone naidina } & Null & 8.274 & - & - & - & - & - & - & - & 182.1 & $>0.1$ \\
\hline & Full & 1003.724 & -66.607 & -119.185 & 1.236 & -5.958 & -1.510 & 0.675 & -0.184 & 203.4 & 21.3 \\
\hline & Optimal & 988.365 & -75.725 & -106.916 & & -4.922 & & & & 182.1 & - \\
\hline \multirow[t]{3}{*}{ Nereis sp. } & Null & 23.110 & - & - & - & - & - & - & - & 211.7 & 6.4 \\
\hline & Full & 1994.677 & -171.788 & -216.463 & 5.651 & -9.760 & 13.928 & 7.192 & 0.017 & 221.1 & 15.8 \\
\hline & Optimal & 844.824 & -171.482 & & & & 16.967 & & & 205.3 & - \\
\hline \multirow[t]{3}{*}{ Syllis sp. } & Null & 6.678 & - & - & - & - & - & - & - & 175.2 & 1.3 \\
\hline & Full & -342.880 & 45.302 & 14.699 & 5.108 & -0.141 & -6.889 & -1.247 & -1.140 & 191.5 & 17.6 \\
\hline & Optimal & -269.866 & 45.615 & & 4.886 & & -6.616 & & -0.908 & 173.9 & - \\
\hline
\end{tabular}

747 
Table 2. (continued 3)

\begin{tabular}{|c|c|c|c|c|c|c|c|c|c|c|c|}
\hline \multirow{2}{*}{ Response } & \multirow{2}{*}{ Model } & \multicolumn{8}{|l|}{ Predictor } & \multirow{2}{*}{$\mathbf{A I C}_{\mathbf{c}}$} & \multirow{2}{*}{$\Delta \mathbf{A I C}_{\mathrm{c}}$} \\
\hline & & (Intercept) & WT & Sal & ZM.bm & ZM.den & Red.alg & Grn.alg & SP.bm & & \\
\hline \multicolumn{12}{|l|}{ Community component } \\
\hline \multirow[t]{3}{*}{ Total invertebrate biomass } & Null & 2.785 & - & - & - & - & - & - & - & 72.0 & 10.3 \\
\hline & Full & 60.096 & -5.936 & -5.985 & 0.214 & -0.097 & 0.456 & 0.184 & 0.056 & 81.0 & 19.3 \\
\hline & Optimal & 23.569 & -4.937 & & 0.219 & & 0.401 & & & 61.7 & - \\
\hline \multirow[t]{3}{*}{ Species richness } & Null & 3.027 & - & - & - & - & - & - & - & 28.0 & 14.7 \\
\hline & Full & 16.581 & -1.485 & -1.211 & 0.080 & -0.094 & -0.036 & 0.080 & -0.023 & 33.6 & 20.3 \\
\hline & Optimal & 13.909 & -2.185 & & & & & & -0.031 & 13.3 & - \\
\hline \multirow[t]{3}{*}{ Species diversity } & Null & 1.255 & - & - & - & - & - & - & - & 19.9 & 8.6 \\
\hline & Full & 2.056 & -0.126 & -0.049 & 0.010 & 0.012 & -0.068 & 0.034 & -0.026 & 36.7 & 25.4 \\
\hline & Optimal & 1.288 & & & & & & 0.065 & -0.020 & 11.3 & - \\
\hline
\end{tabular}

